\title{
POLA NAMA PADA MASYARAKAT BADUY
}

Name Patterns nn Baduy Society

\author{
Cece Sobarna ${ }^{1}$ dan Asri Soraya Afsari ${ }^{2}$ \\ ${ }^{1,2}$ Universitas Padjadjaran \\ ${ }^{1}$ cece@unpad.ac.id, ${ }^{2}$ asri.s.afsari@unpad.ac.id
}

Naskah Diterima Tanggal 12 Februari 2020-Direvisi Akhir Tanggal 13 Oktober 2020-Disetujui Tanggal 13 November 2020 doi: https://doi.org/10.26499/rnh.v9i2.2939

\begin{abstract}
Abstrak
Pemberian nama orang merupakan gejala yang universal. Namun, setiap masyarakat memiliki konvensinya masing-masing. Masyarakat Baduy sebagai indigenous people Sunda memiliki keunikan dalam hal pemberian nama. Kehidupan masyarakat Baduy akhir-akhir ini mulai terbuka. Kondisi ini tentu saja memengaruhi sendisendi kehidupan sosial-budayanya, tidak terkecuali dengan pemberian nama. Kaum milineal Baduy, terutama Baduy Luar, misalnya, lebih bangga memiliki nama yang dianggapnya modern sehingga sebagian dari mereka memiliki nama panggilan yang jauh berbeda dari nama aslinya. Tentu hal ini menjadi sebuah kekhawatiran apabila dibiarkan. Penelitian ini mengkaji pola pemberian nama masyarakat Baduy yang sudah berlangsung sejak lama. Tujuannya adalah mendeskripsikan konvensi pola-pola penamaan sebagai identitas masyarakat Baduy. Data yang dikaji berasal dari sepuluh kampung Baduy Luar dengan memanfaatkan data Kartu Keluarga (KK) yang ada di arsip Kantor Desa Kenekes. Selanjutnya, daftar nama yang terdapat pada KK diolah dengan menggunakan program Microsoft Excel melalui klasifikasi jenis kelamin, rentang usia, dan pola kakonis nama. Hasil penelitian menunjukkan bahwa pola penamaan masyarakat Baduy adalah nama anak perempuan mengambil sebagian, terutama suku kata awal, dari nama ayah, sedangkan nama anak laki-laki mengambil sebagian dari nama ibu. Hal ini berkaitan dengan nilai filosofis yang saling melindungi antara anak dan orang tua.
\end{abstract}

Kata-kata kunci: Baduy, nama, nilai filosofis, pola penamaan

\begin{abstract}
The giving of people's names is a universal phenomenon. However, every society has its own convention. The Baduy community as Sundanese indigenous people are unique in terms of giving names. The life of the Baduy community has recently begun to open up. This condition of course affects the joints of socio-cultural life, including the naming of names. The Baduy millennials, especially the Outer Baduy, for example, are more proud to have a name they consider modern so that some of them have nicknames that are far different from their real names. Of course this is a concern if left unchecked. This study examines the pattern of naming the Baduy community that has been going on for a long time. The aim is to describe the convention of naming patterns as the identity of the Baduy community. The data studied came from ten Outer Baduy villages by using the Family Card $(K K)$ data in the Kenekes Village Office archive. Furthermore, the list of names contained in the KK was processed using the Microsoft Excel program through gender classification, age range, and name standard patterns. The results showed that the naming pattern of the Baduy community was that the names of girls took part, especially the initial syllable, from the father's name, while the names of boys took part of the mother's name. This is related to the philosophical values that protect each other between children and parents.
\end{abstract}

Keywords: Baduy, name, philosophical values, naming pattern

How to Cite: Sobarna, Cece dan Asri Soraya Afsari. (2020). Pola Nama pada Masyarakat Baduy. Ranah: Jurnal Kajian Bahasa. 9(2). 287-300. doi: https://doi.org/10.26499/rnh.v9i2.2939 


\section{PENDAHULUAN}

Pemberian nama pada seseorang atau sesuatu merupakan gejala yang universal ada pada setiap masyarakat. Pemberian nama ini menjadi sangat penting untuk membedakan seseorang/sesuatu tersebut dari yang lain. Dapat kita bayangkan betapa sulitnya kita memanggil seseorang atau menyebut sesuatu mengingat betapa banyaknya manusia dan jenis sesuatu di dunia ini. Oleh karena itu, ada upaya memberi nama melalui konvensi yang dimiliki oleh setiap masyarakat. Seperti masyarakat dunia lainnya, masyarakat Indonesia memiliki pula sistem penamaan ini. Dalam hal pemberian nama ini setiap suku memiliki cara yang berbeda pula. Masyarakat Batak, misalnya, mengenal sistem marga. Marga merupakan famili, bangsa yang terdiri atas orang-orang dari satu keturunan, satu golongan silsilah, golongan-golongan silsilah yang masing-masing mempunyai nama (Nainggolan, 2015: 134). Misalnya, dalam masyarakat Batak Karo dikenal nama lima marga atau merga si lima di antaranya, Ginting, Tarigan, dan Sembiring. Dengan demikian, setiap anggota warga masyarakat Batak Karo termasuk pada salah satu marga ini (Tarigan, 1993: 4).

Tentu pemberian nama ini lain lagi dengan masyarakat Sunda. Sebagaimana dipahami bersama, nama dapat menjadi identitas seseorang atau sekelompok masyarakat. Nama Asep menjadi identitas laki-laki Sunda. Karena begitu kentalnya dengan kesundaan, orang bernama Asep mudah ditemukan di Tatar Sunda sehingga pada tahun 2010 sang pemilik nama ada yang berinisiatif mengumpulkan orang yang bernama Asep di seluruh dunia melalui Paguyuban Asep Dunia (PAD). Masyarakat Baduy, yang terletak di Provinsi Banten, merupakan bagian dari masyarakat Sunda, bahkan orang sering menganggapnya sebagai masyarakat Sunda (yang masih) asli. Dalam hal pemberian nama, masyarakat Baduy termasuk yang memiliki keunikan. Masyarakat Baduy sebagai indigenous people (Hamidi dkk., 2015: iii) memiliki daya tarik, baik dari segi budaya maupun alam. Oleh karena itu, tidak mengherankan apabila setiap harinya banyak orang datang ke tempat ini dengan berbagai keperluan, baik formal maupun nonformal. Dengan demikian, terjadi interaksi yang intens dan masif dengan orang luar yang berlatar belakang berbeda, baik sosial, budaya, maupun ekonomi. Tentu hal ini akan berpengaruh terhadap sendi-sendi kehidupan masyarakat Baduy, tidak terkecuali pula dengan pemberian nama ini. Misalnya, generasi muda Baduy lebih senang menggunakan nama yang dianggapnya modern, seperti Erwin, padahal nama pemberian orang tuanya adalah Antiwin. Hal ini pula yang menimbulkan kesulitan pengurusan administrasi jika mereka berkeperluan karena nama sehari-hari yang mereka gunakan tidak sama dengan nama yang tertera di Kartu Tanda Penduduk (KTP). 
Sebenarnya, masyarakat Baduy memiliki cara tersendiri dalam pemberian nama ini. Nama yang diberikan kepada seorang bayi merupakan hasil "kotemplasi" selama tiga hari tiga malam. Pemberian nama bagi masyarakat Baduy merupakan sesuatu yang sakral karena melewati beberapa tahap ritual. Pada hari ketujuh setelah kelahiran bayi, orang tua mendatangi tetua adat, khususnya dukun, untuk meminta nama yang tepat bagi si bayi tersebut sambil menyerahkan seupaheun, yang meliputi daun sirih kurang lebih lima belas lembar, pinang, dan gambir yang diletakkan di tengah kain putih pesegi empat, lalu dilipat berbentuk tas jinjing supaya bisa digendong. Setelah mendapat petunjuk dari yang gaib (karuhun), ketika si orang tua bayi datang lagi ke dukun, dukun menyampaikan nama yang diperoleh dari impiannya tersebut. Selanjutnya, setelah bayi mendapatkan nama, ritual peureuhan, semacam selamatan pemberian nama, pun dilaksanakan dengan mengundang para tetangga. Pada acara peureuhan ini, hal yang wajib ada adalah seupaheun, yang ditaruh di atas bokor untuk disajikan dan dimakan bersama oleh para tetua kampung. Setelah acara pokok selesai (makan sirih), selanjutnya tetamu menyantap makanan yang disediakan oleh tuan rumah dengan menu utama nasi. Namun, adakalanya nama yang diberikan tidak cocok. Hal ini terjadi bila si bayi cecegekan, misalnya sering menangis, sering sakit, atau bahkan meninggal dunia. Untuk mengatasi ini, ditempuh upaya lain, misalnya dengan cara seolaholah bayi itu "dibuang" ke paraji (dukun beranak) untuk di-pulung 'diambil'. Oleh sebab itu, orang Baduy banyak yang bernama Pulung 'ambil, pungut'. Bahkan, lebih ekstrem lagi ada yang bernama Runtah atau Cudih, yang berarti sampah. Hal ini menarik mengingat pemberian nama Runtah atau Cudih tidak pernah dilakukan oleh masyarakat Sunda di wilayah lainnya.

Penelitian yang terkait dengan nama dapat dikatakan masih jarang. Beberapa tulisan terkait nama pada masyarakat Sunda umumnya dan Baduy khususnya masih sangat terbatas, seperti Danasasmita dan Djatisunda (1986) dan Sobarna (1993). Danasasmita dan Djatisunda mengkaji nama pada masyarakat Kanekes (Baduy) dalam kaitannya dengan pembahasan Kehidupan Masyarakat Kanekes, sedangkan Sobarna mengkaji nama pada masyarakat Sunda sebagai cerminan cara berpikir. Tulisan Sobarna ini sebagai bagian dari tulisan buku bunga rampai Makna Nama dalam Bahasa Nusantara: Sebuah Kajian Antropologi dengan editor Robert Sibarani dan Henry Guntur Tarigan. Dalam buku ini tersaji seluk-beluk penamaan dalam beberapa masyarakat Indonesia, di antaranya Sunda, Batak, Minangkabau, dan Dayak. Penelitian ini bertujuan mendeskripsikan pola penamaan pada masyarakat Baduy yang berlaku selama ini. 


\section{LANDASAN TEORI}

Nama adalah kata atau frasa yang mengidentifikasi baik orang, binatang, tempat, maupun benda secara spesifik. Nama juga menjadi label bagi seseorang atau sesuatu. Pada umumnya orang mengenal hanya satu sistem penamaan. Akan tetapi, pada kenyataannya sistem penamaan ini berbeda-beda pada setiap bangsa (Lawson, 2016: 169). Misalnya, masyarakat Eropa dalam hal pemberian nama menggunakan nama keluarga. Hal ini sudah berlangsung dari abad pertengahan (Cristal, 2015: 103). Sistem nama di berbagai bangsa/suku di dunia memiliki ciri khasnya masing-masing. Edwin D. Lawson (dalam Saito et al., 2015) menyampaikan mengenai sistem penamaan personal names. Lawson (2015) melihat adanya persamaan dan perbedaan sistem nama dari berbagai bahasa dengan mencari benang merah perbedaan tersebut. Lawson (2016) menjelaskan sistem nama di antaranya adalah Aaron Demsky, Bible dari Yahudi; Li Zhonghua dari Cina; dan Philip W. Matthews dari Māori. Aaron Demsky membahas sistem nama Yahudi yang menggunakan nama-nama dari Alkitab. Dalam Alkitab Yahudi terdapat nama-nama pada masa Judas, Kristiani, dan Islam. Namanama Yahudi dibagi atas nama proposional dan epetetik (singkat). Nama proposional seperti YHWH (Yeho/Yahu/Ya/Yo), El, Baal, Shaddai, atau dengan menggunakan gelar, seperti melekh (raja), sar (pangeran), dan 'adon (bangsawan), atau dengan istilah kekerabatan seperti 'ab (ayah), 'am (paman), dan 'ạ (kakak laki-laki). Li Zhonghua menjabarkan penamaan di Cina (Taipe) sangat patuh pada ajaran Confusius. Mereka berkeyakinan bahwa nama adalah cita-cita, 'If a name is not proper, then what is said cannot be followed. If what is said cannot be followed, then nothing can be accomplished'. Cina (Taipe) merupakan bangsa pertama yang menggunakan nama keluarga yang diletakkan sesudah nama diri. Suku Māori di Selandia Baru yang diteliti Philip W. Matthews hanya memiliki nama diri tunggal, seperti Hokotahi. Dengan adanya keterlibatan misionaris di Maori, sistem nama suku Marori berubah dengan memiliki nama lahir dan nama keluarga dengan pola suku Maori dengan nama Maori (M), suku non-Maori dengan nama Maori (X), ketika menggunakan nama keluarga (s) dan nama lahir (g) sebagai berikut.

(1) Ms dan Mg: Parekura Tureia Horomia, Te Puea Herangi.

(2) Ms dan M/X/Ng: Hohepine (kependekan dari Whina) (Josephine) Te Wake, Hone (John) Heke Ngapua.

(3) Xs dan Xg: Kingi Ihaka (King Isaac), Tiaki Omana (Jack Ormond).

(4) Xs dan M/X/Ng: Taurekareka Henare (Henry), Darrin Haimona (Simon).

(5) Ns dan M/X/Ng: Moana Jackson, Wynton Alan Whai Rufer.

(6) Ns and Ng: Peter Russell Sharples, Kees Junior Meeuws.

Ellen S. Bramwell (dalam Saito et al., 2015) juga menyatakan bahwa personal names dapat berkaitan dengan antropologi sebagaimana sistem nama yang dipengaruhi budaya. 
Secara antropologi, kajian tentang nama selalu berkaitan dengan bagaimana nama itu diposisikan dalam masyarakat, oleh siapa nama itu disandang, dan apa manfaatnya untuk masyarakat mereka. Hal ini kuat kaitannya dengan pengelompokan nama bagi orang-orang. Selain nama diri/pribadi, nama tersebut menjadi bentuk klasifikasi, seperti pengelompokan kekerabatan, nama keluarga dan marga patrilineal, atau bahkan klan/suku yang lebih luas. Nama juga memberikan informasi mengenai pekerjaan, asal muasal, atau bahkan keturunan terluhur dapat disematkan dalam nama. Sistem nama yang digunakan dalam komunitas dapat mencakup elemen resmi dan tidak resmi. Nama resmi adalah nama yang dicatat dan didukung oleh negara atau otoritas lain, sedangkan nama tidak resmi biasanya dipertahankan dalam tradisi lisan. Bramwell menyebutkan pembahasan Dickinson (2007) mengenai desa Ukraina. Praktik penamaan pribadi resmi terkait erat dengan pengaruh dan kekuasaan Soviet. Mereka beroperasi dalam domain resmi dan terdiri atas nama depan Ukraina standar, nama patronimik/patriarki, dan nama belakang resmi. Nama-nama ada dalam hubungan diglosik dengan nama tidak resmi, yang hanya digunakan dalam komunitas. Penduduk lokal menggunakan versi dialek dari nama standar Ukraina dan nama panggilan keluarga, di samping nama depan alternatif, nama lokatif, istilah pekerjaan, dan bahkan istilah yang berkaitan dengan harta benda seperti mobil atau kuda tertentu. Klasifikasi penamaan yang kabur ini ada dalam tradisi kategorisasi nama yang dianalisis secara etnografi. Bramwell menyebutkan bahwa Dickinson mengemukakan salah satu fungsi potensial dari sistem diglosik ini adalah untuk menandakan orang dalam dan orang luar melalui penggunaan nama lokal atau resmi.

Ainiala (2012) dalam Names in Focus: An Introduction to Finnish Onomastics menyampaikan bahwa dalam budaya Cina, baik di Cina daratan maupun di Taiwan, seorang anak selalu diberi nama Cina tradisional yang bermakna secara kontekstual sehingga transparan secara semantik. Sistem antroponimik Cina tradisional terdiri atas beberapa jenis nama yang berbeda yang meliputi, misalnya, nama resmi seseorang dan dalam sumber tertulis nama pena, nama panggung yang digunakan oleh seniman, nama agama Buddha, leluhur, nama anumerta, dan berbagai nama julukan. Saat ini, orang Tionghoa memiliki satu nama resmi yang terdiri atas nama keluarga dan nama individu/pribadi.

Budaya Tiongkok memiliki kepercayaan tradisional bahwa nama keluarga dan nama individu secara keseluruhan memiliki, dalam banyak hal, memengaruhi masa depan orang tersebut, seperti pernikahan, karier, properti, kehidupan keluarga, dan hubungannya. Oleh karena itu, nama sama dengan nasib seseorang, bukan sekadar simbol yang membedakan satu 
individu dengan individu lainnya. Untuk alasan ini, nama selalu dipilih dengan cermat. Secara umum, orang Cina menyukai nama yang langka dan bahkan unik. Aturan yang paling penting adalah bahwa nama tidak boleh secara fonetis mengingatkan pada kata-kata yang memiliki arti yang dianggap jahat. Dalam budaya Cina, anak laki-laki biasanya diberi nama yang memberikan keberuntungan, kesehatan, kekayaan, dan kebijaksanaan kepada mereka, sedangkan nama anak perempuan mencerminkan keinginan agar mereka menjadi cantik, seperti rumput. Secara keseluruhan, orang Tionghoa ingin memberikan nama anak mereka dengan nama yang memiliki arti positif, elegan, yang karakternya memiliki sedikit guratan dan mudah diucapkan. Contoh pemberian nama pada orang Tionghoa adalah sebagai berikut.

a. Chinese boys' names
(8) Zhong-yi 'faithful' + 'just'
(9) Shi-zhan 'world' + 'expand'
(10) Wei-cheng 'great' + 'journey'
(11) Chang-xian 'substantial' + 'wise'

b. Chinese girls' names

(12) Chun-hsing 'spring' + 'almond'

(13) Ming-chien 'bright' + 'smile'

(14) Yu-fen 'jade' + 'balm'

(15) Mei-chu 'beautiful' + 'pearl'

Langendonck dalam Theory and Typology of Proper Names (Leroy, 2010) membahas proper names dalam bahasa Inggris sebagai bagian dari kelas sintaktis-semantis. Langendonck menggunakan contoh berikut sebagai ilustrasi.

(16) John attended a meeting today.

(17) The emperor Napoleon was defeated at Waterloo.

(18) You are talking about a different John.

(19) He is becoming a second Napoleon.

Jika diperhatikan secara sintaktis-semantis proper name John, Napoleon, dan Waterloo dalam kalimat (16) dan (17) mengacu pada entitas individu. Secara sintaktis, proper name tersebut berfungsi sebagai frasa nomina, kecuali Napoleon dalam kalimat (17) yang mengacu pada nama raja, sedangkan Napoleon pada kalimat (19) tidak memiliki acuan yang sama dengan kalimat (17). Dengan kata lain, keempat proper name pada kalimat (16) - (19) merupakan nomina umum (common noun).

Praktik nama keluarga tidak dikenal di banyak sistem penamaan Asia lainnya dan sebaliknya, orang mungkin hanya memiliki satu nama. Sistem antroponimi Asia Tenggara (Indonesia, Burma, Thailand) telah dikemukakan oleh Heikkilä-Horn (2002). Misalnya, orang di Pulau Jawa di Indonesia biasanya hanya memiliki satu nama. Dengan demikian, satusatunya nama Suharto, Presiden Indonesia yang menjabat dari tahun 1967 hingga 1998, 
adalah Suharto seperti nama satu-satunya pendahulunya, Sukarno. Walaupun Soekarno menerima nama Kusno dari orang tuanya saat lahir, ia menggantinya saat dewasa menjadi Soekarno, nama ini mengacu pada nama pendekar Karno dari epik India, Mahabharata. Mengganti nama juga cukup umum dalam budaya Indonesia karena tidak ada nama keluarga dalam sistem penamaan Jawa sehingga nama keluarga bukan merupakan nama kerabat/keturunan (baca pula Uhlenbeck, 1982).

Nama keluarga juga tidak dikenal di Myanmar atau Burma. Namun, orang Burma biasanya memiliki setidaknya dua, terkadang bahkan tiga nama. Dengan nama pertama, kita dapat mengetahui pada hari apa anak itu lahir. Misalnya, nama anak yang lahir pada hari Kamis akan diawali dengan huruf pa, pha, $b a$, bha atau ma sesuai dengan abjad India, sedangkan nama anak yang lahir pada hari Minggu akan diawali dengan huruf vokal. Nasehat astrolog diikuti dalam pemberian nama dan nama harus sesuai dengan kepribadian anak. Sama seperti di Cina, sebuah nama bertujuan untuk menjamin masa depan yang sejahtera bagi seorang anak dan terkadang, untuk berjaga-jaga, sang astrolog mendesak keluarga, misalnya, untuk menduplikasi nama anak (Kyaw Kyaw, Mi Mi).

\section{METODE PENELITIAN}

Metode penelitian yang digunakan adalah metode deskriptif. Metode ini dipilih mengingat penelitian penamaan pada masyarakat Baduy berusaha mencoba mencari deskripsi yang tepat dan cukup dari semua aktivitas, objek, proses, dan manusia (Sulystyo-Basuki, 2010: 110). Metode pengumpulan data dalam penelitian antropolinguistik, sebagaimana yang disarankan oleh Sibarani (2004: 51), semula dapat meliputi wawancara mendalam (openended interview) dan observasi (observation), baik observasi-partisipatif maupun observasiperiodik ke lapangan, dan metode kajian tertulis (written document). Namun, mengingat situasi Covid-19 ini, data nama diambil dari Kartu Keluarga (KK) atas seizin aparat Desa Kanekes. Deretan nama pada KK berbentuk Microsoft Word dan terpisah-pisah, lalu disatukan dan ditabelkan. Setelah itu, disalin ke Microsoft Excel.

Data yang sudah terkumpul pada Microsoft Excel selanjutnya dipisahkan kembali berdasarkan kategori dengan menggunakan Pivot Table. Susunan kategorinya meliputi jenis kelamin, usia, nama anak, dan hubungannya dengan nama orang tua; untuk memudahkan pengelompokan digunakan singkatan JUNI (anak laki-laki-ibu) dan JUNA (anak perempuan-ayah). Selanjutnya, data yang sudah dikelompokkan tadi di-filter untuk menemukan pola penamaan, begins with untuk menemukan bagian awal dan ends with untuk 
menemukan bagian akhir. Data KK berasal dari sepuluh kampung yang berada di wilayah Baduy Luar yang dianggap mewakili melalui pemilihan kampung tua dan muda serta berdasarkan arah mata angin. Kampung-kampung tersebut adalah Balingbing, Batara, Cicatang, Cikopeng, Cikadu Babakan, Ciranji Pasir, Cisadane, Gajeboh, Kaduketug 1, dan Kadukohok.

\section{PEMBAHASAN}

Pemberian nama pada masyarakat Baduy umumnya dilakukan melalui tiga upaya. Pertama, pemberian nama dilakukan melalui impian seorang dukun yang biasa diminta pertolongan untuk memberi nama. Jika sang dukun dalam tiga hari tiga malam tidak mendapat pituduh 'petunjuk', dukun menyiapkan beberapa nama untuk kemudian diambil oleh orang tua si bayi. Kedua, pemberian nama dilakukan dengan menyesuaikan hari kelahiran. Jika lahirnya hari Rabu, si bayi diberi nama Rebo, demikian pula dengan hari Kamis, Minggu, dan lain-lain. Ketiga, pemberian nama dilakukan dengan mengambil sebagian nama dari orang tuanya. Anak perempuan akan mengambil sebagian dari nama ayahnya, sedangkan anak laki-laki dari ibunya. Namun, adakalanya tidak demikian. Nama anak dengan orang tuanya tidak berkorespondensi. Hal yang unik dalam hal nama ini adalah jika sudah memiliki anak, orang tua si anak tersebut akan dipanggil sesuai dengan nama anak pertamanya. Misalnya, sepasang suami istri punya anak pertama bernama Sacin, maka sang suami akan dipanggil Ayah Sacin, sedangkan sang ibu akan dipanggil Ambu Sacin. Panggilan ini pula yang terkadang menyulitkan pengurusan administrasi terkait kepemerintahan mengingat nama yang tertera pada $\mathrm{KK}$ adalah nama asli, nama sebelum memiliki anak.

Nama masyarakat Baduy cenderung satu kata, seperti Aming, Jamin, Sarpin, untuk lakilakinya dan Nena, Salnah, Talci untuk perempuan. Akan tetapi, dewasa ini masyarakat Baduy ada yang terdiri atas dua kata, seperti Aat Mardiat, Mae Putri, dan Milla Putri. Bahkan, ada yang tiga kata Silvi Slavina Putri. Pemilik nama-nama tersebut umumnya berasal dari kaum milineal. Nama yang terdiri atas satu kata pada umumnya mengandung dua atau tiga silabe, sedangkan nama yang mengandung empat suku kata sangat jarang. Dari data nama pada sepuluh kampung yang menjadi sampel penelitian hanya ada satu nama, yaitu Sanatarip di Kampung Cikopeng. Begitu pula nama yang terdiri atas satu suku kata tidak yang ditemukan dalam penelitian ini. Data berikut merupakan nama yang terdiri atas satu unsur dengan dua dan tiga suku kata. 
a. Nama dengan dua suku kata
(20) Arni -- Ar-ni
(21) Arpin ---- Ar-pin
(21) Narsi ---- Nar-si
(21) Misnan ---- Mis-nan
(22) Sardi ---- Sar-di

b. Nama dengan tiga suku kata
(23) Anijah ---- A-ni-jah
(24) Caikin ---- Cai-kin
(25) Janawi ---- Ja-na-wi
(25) Naipah ---- Nai-pah
(26) Sarkawi ---- Sar-ka-wi

Sebagaimana telah dijelaskan, dalam pemberian nama, masyarakat Baduy memiliki kebiasaan mengaitkan nama anak dengan nama orang tuanya. Berikut ini pola-pola pemberian nama yang terdapat di sepuluh kampung Baduy Luar.

\section{Suku kata awal nama orang tua sama dengan suku kata awal nama anak}

Berikut adalah kelompok nama anak perempuan yang memiliki suku kata turunan dari ayah.

Tabel 1.

Nama Anak Perempuan

\begin{tabular}{llll}
\hline Nama Ayah & Nama Anak Perempuan & Fonotaktik & $\begin{array}{c}\text { Usia Anak } \\
\text { Perempuan }\end{array}$ \\
\hline ARIM & ARNI & V1K1 & P. 12-25 tahun \\
\hline ARJA'I & ARSINAH & V1K1 & P. 26-45 tahun \\
\hline ARDI & ARSUNAH & V1K1 & P. 26-45 tahun \\
\hline CAIWIN & CALINAH & K1V1 & P. 26-45 tahun \\
\hline CALCIN & CAINTEN & K1V1 & P.46-100 tahun \\
\hline CARMA & CASITI & K1V1 & P. 12-25 tahun \\
\hline CARMA & CANI & K1V1 & P. 12-25 tahun \\
\hline KACIN & KASINAH & K1V1 & P. 26-45 tahun \\
\hline KARIM & KARSAH & K1V1 & P. 12-25 tahun \\
\hline KARIM & KARSAH & K1V1 & P.46-100 tahun \\
\hline SADI & SANI & K1V1 & P. 12-25 tahun \\
\hline SAMIN & SATI & K1V1 & P. 0-11 tahun \\
\hline SAMIN & SANI & K1V1 & P. 12-25 tahun \\
\hline SARKA & SARAH & K1V1 & P. 12-25 tahun \\
\hline SARNA & SARPAH & K1V1 & P. 0-11 tahun \\
\hline
\end{tabular}

Tabel 1 di atas menunjukkan bahwa jika nama ayah diawali dengan suku kata $A$-, Ari-, $\mathrm{Ca}$-, $\mathrm{Ka}, \mathrm{Sa}$-, dan $\mathrm{Sar}-$, nama anak perempuan akan diawali dengan penggalan yang sama persis seperti nama ayah, seperti Ar-ni, Ar-sinah, Ca-linah, Ca-inten, Ca-siti, Ca-ni, Kasinah, Kar-sah, Sa-ti, Sa-rah, dan Sar-pah. Konsepsi ini ditemukan pada kelompok anak dengan usia 0 -11 tahun, 12-25 tahun, 26-45 tahun, dan 46-100 tahun. Kesamaan suku 
kata di awal tersebut menunjukkan bahwa proses silang terjadi dalam pemberian nama di suku Baduy, yaitu nama anak perempuan berasal dari nama ayah.

Berikut adalah kelompok nama anak laki-laki yang memiliki suku kata turunan dari ibu.

Tabel 2.

Nama Anak Laki-laki

\begin{tabular}{llll}
\hline \multicolumn{1}{c}{ Nama Ibu } & \multicolumn{1}{c}{ Nama Anak Laki- } & Fonotaktik & \multicolumn{1}{c}{$\begin{array}{c}\text { Usia Anak Laki- } \\
\text { Laki }\end{array}$} \\
\hline ACIH & ARKAN & V1 & L.11-25 tahun \\
\hline ACIH & AMIR & V1 & L.11-25 tahun \\
\hline ARSUNAH & ARSIM & V1 & L. 0-11 tahun \\
\hline ARSUNAH & ARKAM & V1 & L.11-25 tahun \\
\hline ARUM & ARJA & V1 & L. 26-45 tahun \\
\hline ARUM & ARDA & V1 & L. 26-45 tahun \\
\hline ARBA & ARSAD & V1 & L. 46-100 tahun \\
\hline CAIAH & CAIKIN & K1V1 & L. 46-100 tahun \\
\hline CASITI & CASMA & K1V1 & L. 0-11 tahun \\
\hline KARNI & KARSIM & K1V1 & L. 0-11 tahun \\
\hline KASITI & KASMIN & K1V1 & L. 0-11 tahun \\
\hline KARTINAH & KARDI & K1V1 & L.11-25 tahun \\
\hline SANI & SADI & K1V1 & L. 0-11 tahun \\
\hline SANIAH & SANA & K1V1 & L.11-25 tahun \\
\hline SARIKAH & SARUDIN & K1V1 & L.11-25 tahun \\
\hline SARTI & SARDA & K1V1 & L. 26-45 tahun \\
\hline TACI & TAKI & K1V1 & L. 46-100 tahun \\
\hline
\end{tabular}

Tabel 2 di atas menunjukkan bahwa jika nama ibu diawali dengan suku kata A-, Ari-, $\mathrm{Ca}$-, $\mathrm{Ka}$, Sa-, Sar-, dan $\mathrm{Ta}$-, nama anak laki-laki akan diawali dengan penggalan yang sama persis seperti nama ibu seperti Ar, seperti Ar-kan, A-mir, Ar-ja, Ca-ikin, Cas-ma, Kar-sim, Kar-di, Sa-di, Sar-di, dan Ta-ki. Konsepsi ini ditemukan pada kelompok anak dengan usia 0-11 tahun, 12-25 tahun, 26-45 tahun, dan 46-100 tahun. Kesamaan suku kata di awal tersebut menunjukkan bahwa proses silang terjadi dalam pemberian nama di suku Baduy, yaitu nama anak laki-laki berasal dari nama ibu.

\section{Suku kata awal nama orang tua sama dengan suku kata awal nama anak, tetapi berbeda konsonan/vokal akhirnya}

Berikut adalah kelompok nama anak perempuan yang memiliki suku kata turunan dari ayah, tetapi ada perubahan pada konsonan atau vokal akhir dari suku kata pertama tersebut. 
Tabel 3.

Nama Anak Perempuan

\begin{tabular}{llll}
\hline Nama Ayah & Nama Anak Perempuan & Fonotaktik & \multicolumn{1}{c}{$\begin{array}{c}\text { Usia Anak } \\
\text { Perempuan }\end{array}$} \\
\hline ARSAH & ASBAH & K2K3V1 & P. 26-45 tahun \\
\hline ARKA & SARNI & V1 & P.46-100 tahun \\
\hline ARSILIN & SARWI & V1 & P. 26-45 tahun \\
\hline CAIKIN & CARSAH & K1V1 & P. 12-25 tahun \\
\hline DALKIN & DARWIS & K1V1V2 & P. 26-45 tahun \\
\hline DARMIN & DALIS & K1V1V2 & P. 26-45 tahun \\
\hline DARMIN & DAISAH & K1V1V2 & P. 26-45 tahun \\
\hline KAIRAN & KASTI & K1V1 & P. 12-25 tahun \\
\hline
\end{tabular}

Tabel 3 di atas menunjukkan bahwa apabila nama ayah diawali dengan suku kata Ar-, nama anak akan diawali dengan $A s$-bah. Selain itu, ada juga nama ayah yang diawali dengan suku kata Ar- maka nama anak akan diawali dengan Sar-ni dan Sar-wi. Nama ayah diawali dengan suku kata Dar- maka nama anak akan diawali dengan Da-lis dan Da-isah. Nama ayah diawali dengan suku kata $D a$ - maka nama anak akan diawali dengan Kas-ti. Konsepsi ini ditemukan pada kelompok anak dengan usia 12-25 tahun dan 26-45 tahun. Perubahan pada awal atau akhir suku kata pertama tersebut menunjukkan bahwa terjadi proses pelesapan ataupun penurunan bunyi r $\sim$ s, penambahan $s$ dari Ar- menjadi Sar, $\mathrm{Ka}$ - menjadi Kas-, $\mathrm{Ca}$ menjadi Car-, dan perubahan 1 r di Dar-menjadi Dal-. Pemberian nama silang tetap terjadi dalam pemberian nama di suku Baduy, yaitu nama anak laki-laki berasal dari nama ibu.

Berikut adalah kelompok nama anak laki-laki yang memiliki suku kata turunan dari ibu, tetapi ada perubahan pada konsonan atau vokal akhir dari suku kata pertama tersebut.

Tabel 4.

Nama Anak Laki-laki

\begin{tabular}{llll}
\hline Nama Ibu & Nama Anak Laki-laki & Fonotaktik & Usia Anak Laki-laki \\
\hline ARBA & ANDI & V1K1 & L.11-25 tahun \\
\hline ARBA & ALDI & V1K1 & L.11-25 tahun \\
\hline ARMAH & ASJA & V1K1 & L.11-25 tahun \\
\hline KARIBAH & KALDI & K1V1 & L.11-25 tahun \\
\hline KARIDAH & KASIM & K1V1 & L. 26-45 tahun \\
\hline KASBAH & KARDI & K1V1 & L.11-25 tahun \\
\hline SAINAH & SARJA & K1V1 & L.11-25 tahun \\
\hline SAIPAH & SARPIN & K1V1 & L. 46-100 tahun \\
\hline SAKINAH & SARDI & K1V1 & L.11-25 tahun \\
\hline SARWI & SALDI & K1V1 & L.11-25 tahun \\
\hline TALCI & TARDI & K1V1 & L. 0-11 tahun \\
\hline TALCI & TALIM & K1V1 & L. 0-11 tahun \\
\hline TARWI & SARDA & K1V1 & L. 26-45 tahun \\
\hline
\end{tabular}




\begin{tabular}{llll}
\hline Nama Ibu & Nama Anak Laki-laki & Fonotaktik & Usia Anak Laki-laki \\
\hline YALCI & JAHADI & K1V1 & L. 26-45 tahun \\
\hline YALCI & JAKIM & K1V1 & L. 26-45 tahun \\
\hline YANTI & JALI & K1V1 & L. 26-45 tahun \\
\hline YASCEU & JAMA & K1V1 & L.11-25 tahun \\
\hline
\end{tabular}

Tabel 4 di atas menunjukkan bahwa jika nama ibu diawali dengan suku kata $A r$-, nama anak akan diawali dengan $A n-d i, A l-d i$, dan As-ja. Selain itu, ada juga nama ibu yang diawali dengan suku kata Kar- maka nama anak akan diawali dengan Kal-di, Ka-sim, dan sebaliknya jika nama ibu diawali Kas-, nama anak akan diawali Kar-di. Nama ibu diawali dengan suku kata $S a$ - maka nama anak akan diawali dengan Sar-pin dan Sar-di. Nama ibu diawali dengan suku kata Tal- maka nama anak akan diawali dengan Ta-lim. Nama ibu diawali dengan suku kata Tar- maka nama anak akan diawali dengan Sar-da. Nama ibu diawali dengan suku kata Yal- maka nama anak akan diawali dengan Ja-hadi dan Ja-kim. Nama ibu diawali dengan suku kata Yan- maka nama anak akan diawali dengan Ja-li dan Ja-ma. Konsepsi ini ditemukan pada kelompok anak dengan usia 0-11 tahun, 12-25 tahun dan 26-45 tahun. Perubahan pada awal atau akhir suku kata pertama tersebut menunjukkan bahwa terjadi proses pelesapan ataupun penurunan bunyi $r$ menjadi $l$ dan $s$. Hal yang sama juga terjadi pada s r. Penambahan $r$ dari Sa- menjadi Sar- dan perubahan Yal- dan Yas- menjadi Ja-. Pemberian nama silang tetap terjadi dalam pemberian nama di suku Baduy, yaitu nama anak laki-laki berasal dari nama ibu.

\section{Suku kata awal nama orang tua sama dengan suku kata awal nama anak, tetapi mendapat penghilangan konsonan atau vokal pada nama anak}

Berikut adalah kelompok nama anak perempuan yang memiliki suku kata turunan dari ayah, tetapi ada penghilangan pada konsonan atau vokal akhir dari suku kata pertama tersebut.

Tabel 5.

Nama Anak Perempuan

\begin{tabular}{cccc}
\hline Nama Ayah & $\begin{array}{c}\text { Nama Anak } \\
\text { perempuan }\end{array}$ & Fonotaktik & Usia Anak Perempuan \\
\hline SATAR & ARNI & K1V1 & P. 0-11 tahun \\
SARNA & SATI & K1V1 & P. 0-11 tahun \\
\hline SALMIN & SAMI & K1V1 & P. 12-25 tahun \\
\hline
\end{tabular}

Tabel 5 di atas menunjukkan bahwa jika nama ayah diawali dengan suku kata $\mathrm{Sa}$-, Sardan Sal-, nama anak akan diawali dengan Ar-ni, Sa-ti, dan Sa-mi: pelesapan atau 
penghilangan huruf (konsonan/vokal) di awal, seperti Sa-tar menjadi Ar-ni; pelesapan/penghilangan huruf (konsonan/vokal) di tengah, seperti Sar-na menjadi Sa-ti dan Sal-min menjadi Sa-mi. Konsepsi ini ditemukan pada kelompok anak dengan usia $0-11$ tahun dan $12-25$ tahun. Pemberian nama silang tetap terjadi dalam pemberian nama di suku Baduy, yaitu nama anak perempuan berasal dari nama ayah.

Berikut adalah kelompok nama anak laki-laki yang memiliki suku kata turunan dari ibu, tetapi ada penghilangan pada konsonan atau vokal akhir dari suku kata pertama tersebut.

Tabel 6.

Nama Anak Laki-laki

\begin{tabular}{lccc}
\hline \multicolumn{1}{c}{ Nama Ibu } & Nama Anak Laki-laki & Fonotaktik & Usia Anak Laki-laki \\
\hline CANIRAH & ASJA & K1V1 & L.11-25 tahun \\
\hline CANIRAH & ARJA & K1V1 & L. 26-45 tahun \\
\hline KARNI & ARJI & K1V1 & L. 26-45 tahun \\
\hline
\end{tabular}

Tabel 6 di atas menunjukkan bahwa jika nama ibu diawali dengan suku kata $\mathrm{Ca}$ - dan Kar-, nama anak akan diawali dengan As-ja, Ar-ja, dan Ar-ji. Pelesapan atau penghilangan huruf (konsonan/vokal) terjadi di awal, seperti Ca-nirah menjadi As-ja dan Ar-ja, dan Kar-ni menjadi Ar-ji. Konsepsi ini ditemukan pada kelompok anak dengan usia 11-25 tahun dan 26-45 tahun. Pemberian nama silang tetap terjadi dalam pemberian nama di suku Baduy, yaitu nama anak laki-laki berasal dari nama ibu.

\section{PENUTUP}

Berdasarkan hasil kajian terhadap pola penamaan suku Baduy, ada beberapa konsepsi penggunaan suku kata pertama pada anak dan konsepsi pemberian nama silang secara jenis kelamin anak. Konsepsi suku kata pertama ayah/ibu yang digunakan pada anak perempuan/laki-laki dapat diturunkan seutuhnya, seperti Arbi-Arni diturunkan sebagian atau berubah seperti Tardi-Talci ataupun mengalami pelesapan seperti Karni-Arji. Penggunaan suku kata pertama nama ayah yang diturunkan pada anak perempuan dan nama ibu ke anak laki-laki menunjukkan filosofi ayah yang melindungi anak perempuannya dan anak laki-laki yang melindungi ibunya.

\section{DAFTAR PUSTAKA}

Ainiala, T., Saarelma, M., \& Sjoblom, P. (2012). Names in Focus: An Introduction to Finnish Onomastics. https://doi.org/10.21435/sflin.17

Crystal, David. (2015). Ensiklopedi Bahasa. Terjemahan Rahmani Astuti dari The Cambridge Encyclopedia of Language. Bandung: Nuansa Cendekia. 
Danasasmita, Saleh dan Anis Djatisunda. (1986). Kehidupan Masyarakat Kanenes. Bandung: Bagian Proyek Penelitian dan Pengkajian Kebudayaan Sunda (Sundanologi), Direktorat Jenderal Kebudayaan, Departemen Pendidikan dan Kebudayaan

Hamidi, Jazim dkk. (2015). Demokrasi Lokal nurut Masyarakat Baduy. Malang: Nuswantara.

Lawson, Edwin D. (2016). Personal Naming Systems. Dalam Carole Hough (Ed.) Names And Naming. Oxford: Oxford University Press. https://doi.org/10.1093/oxfordhb-/9780199656431.013.31

Leroy, S. (2010). Theory and Typology of Proper Names. Dalam Nouvelle revue d'onomastique. $52(1)$

Nainggolan, Togar. (2015). Strategi Komunitas Batak Toba untuk Penguatan Karakter Bangsa. Dalam Bungaran Antonius Simanjuntak (Peny.) Karakter Batak: Masa Lalu, Kini, dan Masa Depan. Jakarta: Yayasan Pustaka Obor.

Saito, M., Trousdale, G., Gibson, K., Gut, U., \& Kristoffersen, G. (2015). Handbooks in Linguistics. Oxford.

Sibarani, Robert. (2004). Antropolinguistik. Medan: Poda.

Sobarna, Cece. (1993). Makna Nama: Cara Berpikir Masyarakat Sunda. Dalam Robert Sibarani dan Henry Guntur Tarigan (Peny.) Makna Nama dalam Bahasa Nusantara: Sebuah Kajian Antropolinguistik. Bandung: Bumi Siliwangi.

Sulistyo-Basuki. (2010). Metode Penelitian. Jakarta: Penaku.

Tarigan, Henry Guntur. (1993). Nilai Nama pada Masyarakat Karo. Dalam Robert Sibarani dan Henry Guntur Tarigan (Peny.) Makna Nama dalam Bahasa Nusantara: Sebuah Kajian Antropolinguistik. Bandung: Bumi Siliwangi.

Uhlenbeck, E.M. (1982). Kajian Morfologi Bahasa Jawa. Terjemahan Soenarjati Djajanegara dari Studies in Javanese Morphology. Jakarta: Djambatan. 